\title{
Biochemical responses of the earthworm Allolobophora caliginosa exposed to cadmium contaminated soil in the Northeast of Algeria.
}

Manuscrit reçu le 6 octobre 2017 et accepté le 12janvier 2018

Hadjer OTMANI ${ }^{1}$, Aicha TADJINE ${ }^{2}$, Ouissem MOUMENI ${ }^{1}$, Ibtissem ZERIRI ${ }^{1}$, Rima AMAMrA ${ }^{1}$, Djekoun Bensoltane SAMIRA ${ }^{1}$, Mohamed Reda DJEBAR ${ }^{1}$, and Houria BERREBBAH ${ }^{1}$.

${ }^{1}$ Cellular Toxicology Laboratory, Department of Biology, University of Badji Mokhtar Annaba, Algeria.

${ }^{2}$ Functional and Evolutionary Ecology Laboratory, Department of Biology, University of Chadli Bendjedid, El Tarf, Algeria.

\section{Résumé}

Les réponses de vers de terre Allolobophora caliginosa aux expositions sub-létales de cadmium $(\mathrm{Cd})(25,50,100,150 \mathrm{mg} / 500 \mathrm{~g}$ d.w), ont été examinées dans cette étude. L'Enquête a été faite sur le taux de protéines totales, le stress oxydatif et la réponse antioxydante à travers un ensemble de biomarqueurs enzymatiques ((catalase (CAT), glutathione (GSH), glutathione S-transferase (GST) et malondialdehyde (MDA)), qui ont été choisie pour évaluer les réponses des vers de terre dans une période jusqu'à deux semaines. Les vers de terre exposés au cadmium ont démontré différentes réponses des biomarqueurs enzymatiques. Le cadmium a augmenté le taux de protéines totales. De plus, la surveillance des biomarqueurs de stress oxydatif a montré un épuisement significatif au niveau du glutathione (GSH) accompagné d'une forte augmentation de glutathione S-transferase (GST) et de la stimulation de l'activité catalase (CAT) et malondialdehyde (MDA). Nos résultats indiquent les effets toxiques du cadmium sur les vers de terre Allolobophora caliginosa.

Mots clés: Cadmium, Allolobophora caliginosa, protéines totales, stress oxydatif, Biomarqueurs.

\begin{abstract}
The responses of earthworms Allolobophora caliginosa to sub-lethal exposures of cadmium $(\mathrm{Cd})(25,50,100,150 \mathrm{mg} / 500 \mathrm{~g} \mathrm{d.w})$, were investigated in this study. Investigation was done on the total proteins rate, oxidative stress, and antioxidative response through a set of enzymatic biomarkers ((catalase (CAT), glutathione (GSH), glutathione S-transferase (GST) and malondialdehyde (MDA)), which were selected to evaluate the responses of the earthworms in a period up to two weeks. The earthworms exposed to the cadmium stress demonstrated different responses of the enzymatic biomarkers. Cadmium stress increased the total proteins rate. Furthermore, monitoring biomarkers of oxidative stress showed a significant depletion in glutathione level (GSH) accompanied with a strong increase of glutathione S-transferase (GST) and stimulation of catalase activitie (CAT) and
\end{abstract}


malondialdehyde (MDA). Our results indicated the toxic effects of cadmium on Allolobophora caliginosa earthworms.

Keywords : Cadmium, Allolobophora caliginosa, total proteins, Oxidative stress, Biomarkers.

\section{Introduction}

Widely spread in the environment from anthropogenic sources, Heavy metals have caused damages to ecosystems close to emission sources (Derome and Nieminen, 1998). Although they are essential trace elements, metals above certain concentrations and exposure times are toxic to soil animals and affect the abundance, diversity, and distribution of the animals (Hopkin, 1989). In many ecosystems, earthworms play a major role in the development and maintenance of soil structure. They have a great impact on soil decomposition activity, on nutrient mineralization, and hence on primary productivity (Edwards and Bohlen, 1996). Earthworms play a key role in many soil processes and are in full contact with the soil solution, thus they are relevant indicators of environmental change and have been included in a group of five key indicators for ecotoxicological testing of industrial chemicals determined by the Organization de Cooperation et de Developpement Economiques and the European Economic Community (Capowiez et al., 2003). Earthworms are more susceptible to metal pollution than many other groups of soil invertebrates (Bengtsson et al., 1992). Considering their relative sensitivity, toxicity data from earthworms are important in determining safe levels for metals in soil (Spurgeon and Hopkin, 1996). This species accumulate high concentrations of metals from contaminated soil (Morgan and Morgan, 1999). Cadmium is a non-essential heavy metal is very toxic and have particularly harmful effects on organisms (CEPA, 1994). It is effectively lethal to earthworms and particularly affects earthworms growth and reproduction (Matthias, 2010). Many previous studies focused on Cd effects on earthworms E. fetida' survival, reproduction and even the responses of detoxification system as well. While the effects of high-level $\mathrm{Cd}$ on earthworms Allolobophora caliginosa (an abundant species in the region of Seraidi-Annaba) are rarely reported, that's what the present work carried to investigate. The main aim of this study was to evaluate the effects of cadmium on the growth, oxidative stress, and antioxidative response through a set of enzymatic biomarkers (CAT, GSH, GST and MDA) of earthworms Allolobophora caliginosa upto two weeks, and to provide valuable information for ecological risk assessment of the cadmium effects at environmentally relevant levels.

\section{Materials and methods}

\subsection{Biological material}

Adult (clitellate) earthworms (Allolobophora caliginosa), weight subsequently found to average $1.5 \mathrm{~g}$, were collected from Séraidi region near Annaba (East of Algeria). They were randomly assigned to treatment groups, either their native substrate (soil) under laboratory conditions $\left(20 \pm 1^{\circ} \mathrm{C} ; 12 \mathrm{~h}\right.$ dark/12 h light). 


\subsection{Chemical material and soil amendment}

Cadmium chloride $\left(\mathrm{CdCl}_{2}\right.$ pentahydrate, Fluka) was the chemical product used in our experiment. Deionized water was used as vehicle to spike soil with cadmium. Solutions were prepared to obtain the following nominal concentration in soil: 0 (control), 25, 50, 100, 150 $\mathrm{mg} / 500 \mathrm{~g}$ d.w. Soils were kept at $20^{\circ} \mathrm{C}$ for 14 days after spiking and before the beginning of the assays. Deionized water and Cd solutions were added to get $75 \%$ of the soil water holding capacity (WHC).

\subsection{Exposure and measurements}

The worms were weighed and exposed at different concentrations of Cd-spiked soil (500 $\mathrm{g}$ d.w.) in terrariums, with 5 adults per terrarium and for each concentration. Humidity in terrariums was adjusted by adding deionized water if necessary (12-15\% humidity). Worms were fed with 2 grams of dried cereals, every week. After 7 and 14 days earthworms were then collected and purged during $24 \mathrm{~h}$, then weighted. The worms were cut into five portions for analysis of various parameters. Total proteins content was measured according to the method of Bradford (1976). The determination of glutathione rate (GSH) was realized according to the method of Weckberker and Croy (1988). The measurement of glutathion-Stransferase (GST) activity was realized according to the method of Habig et al. (1974). The catalase activity measurement (CAT) was followed according to the method of Regoli and Principato (1995). The rate of malondialdehyde (MDA) was measured according to the method of Draper and Hadley (1990).

\subsection{Stastical analysis}

The obtained results were expressed as the Mean \pm Standard Deviation (SD) with three independent replicates. Data were analyzed by one-way analysis of variance (ANOVA). To look for differences by pairs between treated samples and the control, we applied the Student's t-test. Statistical analyses were performed using the Minitab software (14.0).

\section{Results}

\subsection{Total proteins rate}

Data are the mean \pm S.E. of three replicates. In the period of 7 days, a significant increase in the total proteins rate compared with the control was observed following exposure to the lowest concentration of cadmium $25 \mathrm{mg} / 500 \mathrm{~g}$ d.w ( $p=0.016$ ), and for worms treated with the highest concentration of cadmium $150 \mathrm{mg} / 500 \mathrm{~g}$ d.w this rate was very highly significantly increased to be $4.47 \pm 1.59$ when compared to the control $2.55 \pm 0.13 \mu \mathrm{M} \mathrm{mg}^{-1}$ of tissues $(p=0.001)$. However, the effects of cadmium were less intense in the concentrations of 50 and $100 \mathrm{mg} / 500 \mathrm{~g} \mathrm{d.w}$, where there were no significant differences in the total proteins rate compared with the control. While in a period of 14 days, the exposure of worms to cadmium resulted in no significant decrease of the total proteins rate compared with the control 
$\mathrm{p}=0.156$. Significant differences from the control are indicated as: $\mathrm{p} \leq 0.05\left(^{*}\right)$ and $\mathrm{p} \leq 0,001$ $(* * *)$ very highly significant (Fig.1).

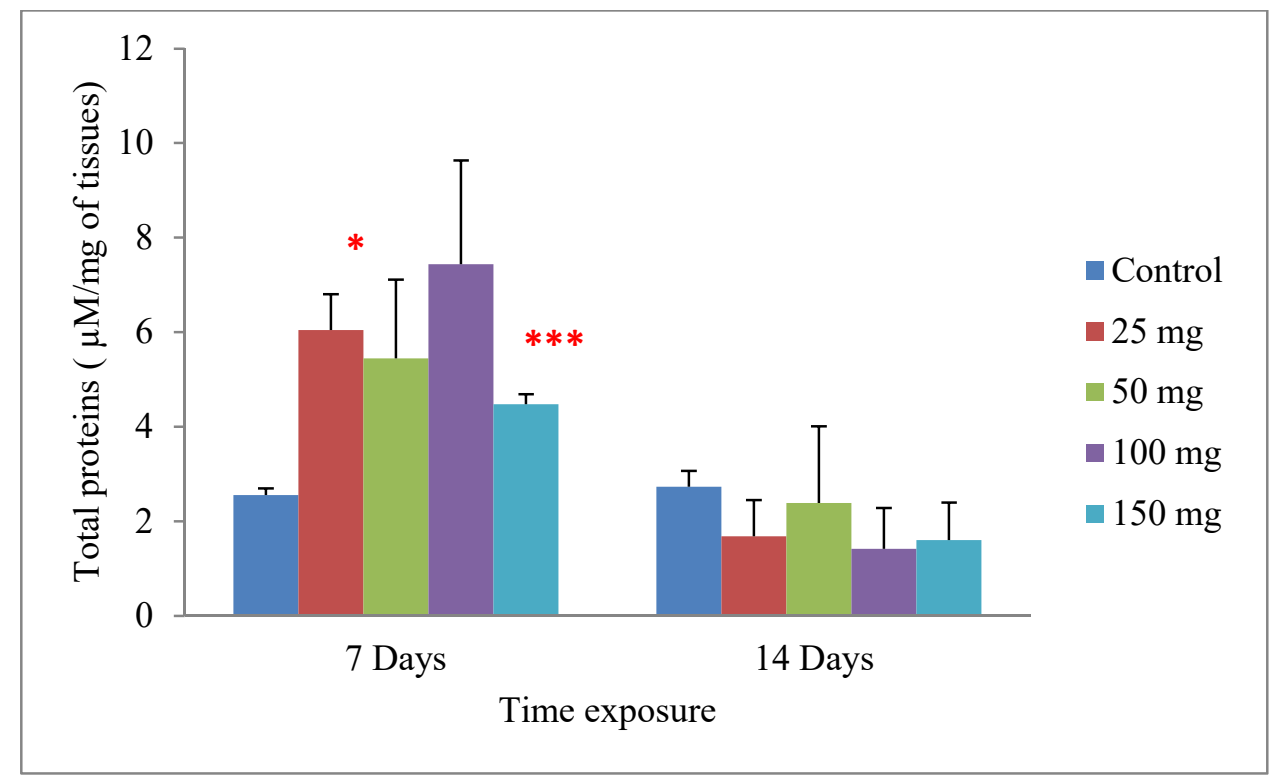

Fig.1: Effect of cadmium stress on the total proteins rate in Allolobophora caliginosa

\subsection{GSH rate}

Data are the mean \pm S.E. of three replicates. A non-significant increase in the GSH rate compared with the control was observed following exposure to all concentrations of cadmium in a period of 7 days. However in a period of 14 days, it was found that cadmium causes a dose dependent decrease in the GSH level. Compared to the control (3.60 \pm 0.16$)$, GSH level was significantly determinate to be $2.04 \pm 0.46 \mu \mathrm{mol} \mathrm{mg}^{-1}$ protein $(\mathrm{p}=0.031)$ in earthworms treated with the concentration of $50 \mathrm{mg} / 500 \mathrm{~g}$ d.w. For worms treated with 100 and 150 $\mathrm{mg} / 500 \mathrm{~g}$ d.w this rate was very highly significantly reduced to be $1.22 \pm 0.26$ and $1.31 \pm 0.28$

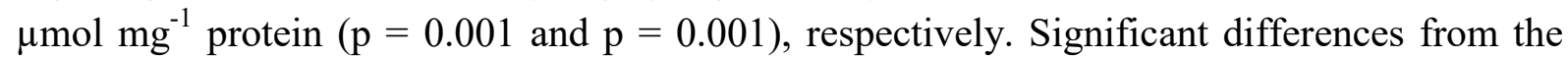
control are indicated as: $\mathrm{p} \leq 0.05\left(^{*}\right)$ and $\mathrm{p} \leq 0,001(* * *)$ very highly significant. (Fig.2). 


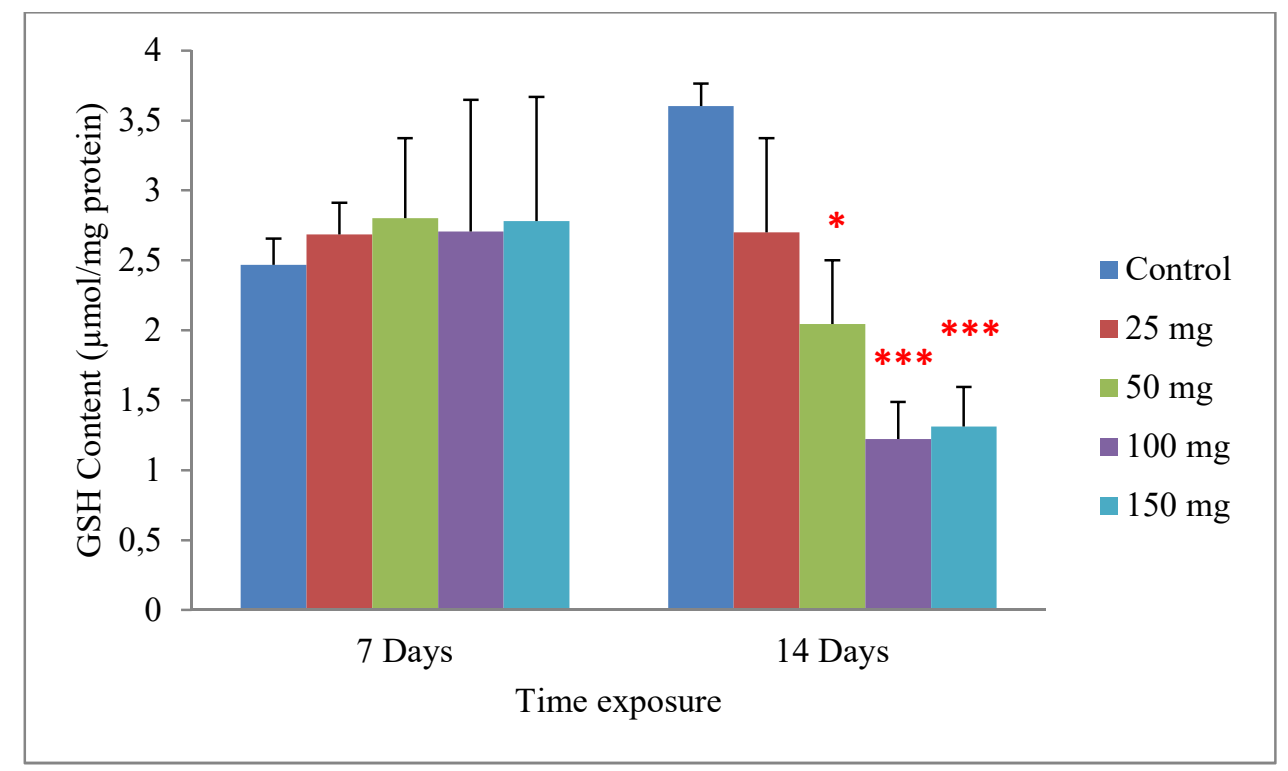

Fig. 2: Effect of cadmium stress on the GSH rate in Allolobophora caliginosa

\subsection{GST rate}

Data are the mean \pm S.E. of three replicates. In the period of 7 days, GST activity showed a tendency of decrease, but only became significant $(\mathrm{P}<0.05)$ with concentrations 50 and 150 $\mathrm{mg} / 500 \mathrm{~g}$ d.w compared to the control. While in a period of 14 days, the exposure of worms to cadmium resulted in an induction of the GST activity. The enzymatic activity appeared with concentrations 25,100 and $150 \mathrm{mg} / 500 \mathrm{~g} \mathrm{~d} . \mathrm{w}$, which had significant increase when compared to the control $(p=0.043, p=0.023$ and $p=0.043)$, respectively. However, the effects of cadmium were less intense in the concentration $50 \mathrm{mg} / 500 \mathrm{~g} \mathrm{~d} . \mathrm{w}$, where there were no significant differences in GST activity $\mathrm{p}=0.123$. Significant differences from the control are indicated as: $\mathrm{p} \leq 0.05(*)$ (Fig.3).

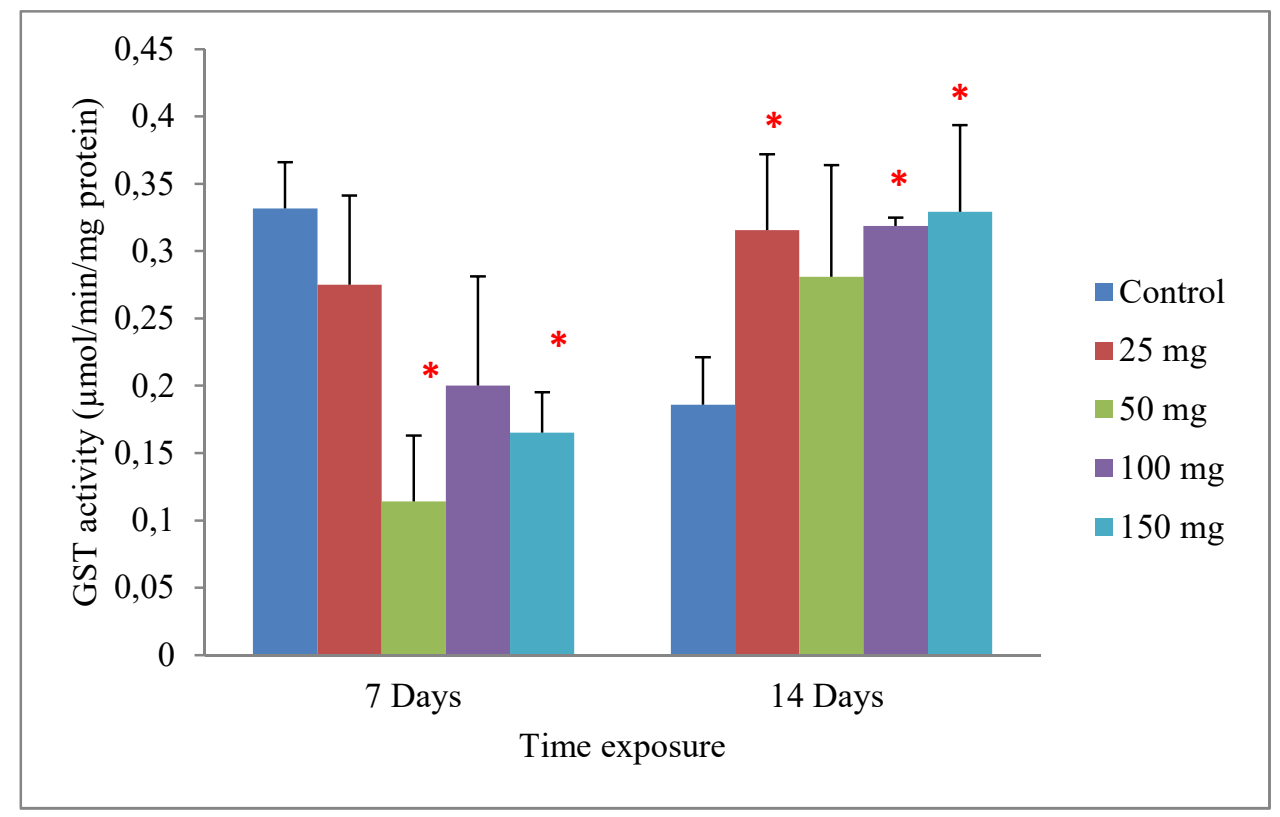

Fig.3: Effect of cadmium stress on the GST activity in Allolobophora caliginosa 
Bulletin de la Société Royale des Sciences de Liège, Vol. 87, articles, 2018, p. 1 - 12

\subsection{CAT activity}

Data are the mean \pm S.E. of three replicates. The results show a non-significant increase in CAT activity compared with the control, in presence of the xenobiotic (Fig.4).

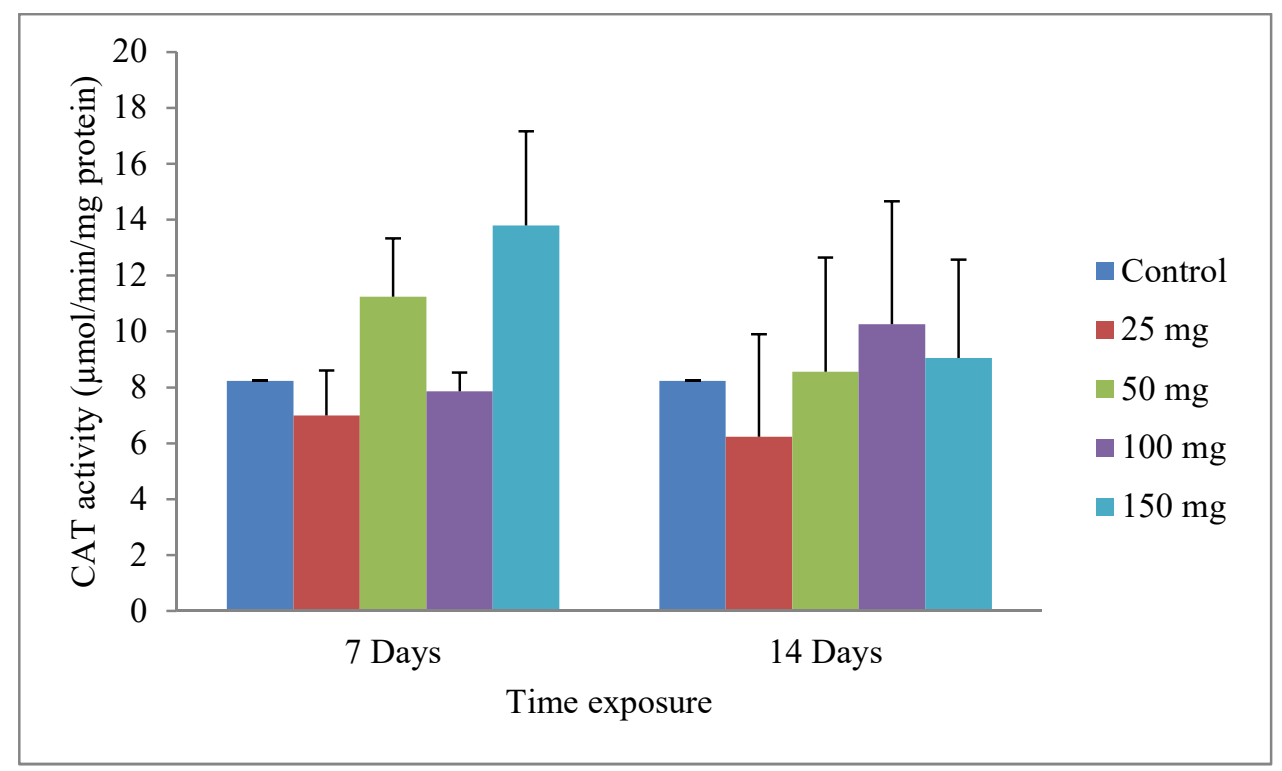

Fig.4: Effect of cadmium stress on the CAT activity in Allolobophora caliginosa

\subsection{MDA level}

Data are the mean \pm S.E. of three replicates. The results show a non-significant increase in MDA level compared with the control, in presence of the cadmium (Fig.5).

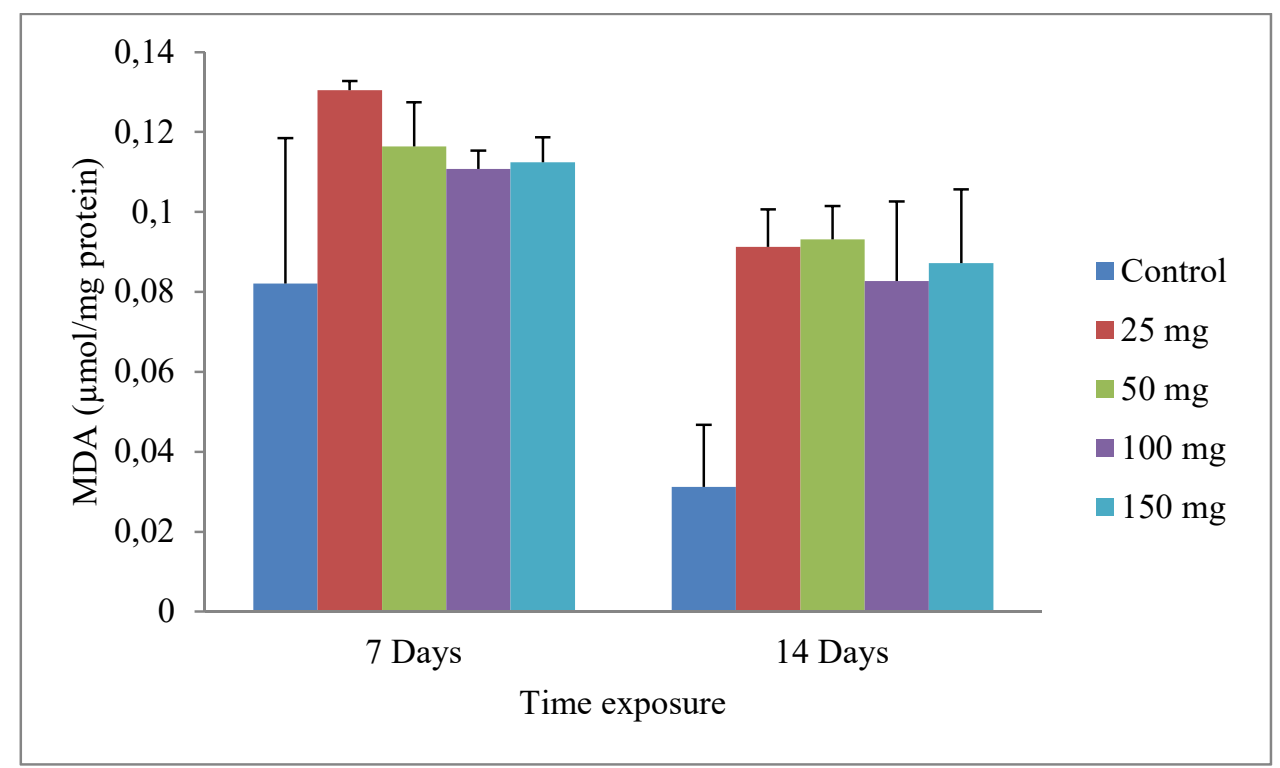

Fig.5: Effect of cadmium stress on MDA level in Allolobophora caliginosa 


\section{Discussion}

In agricultural ecosystems, where animal farming and related agricultural practices are intensive, heavy metals can also reach the soil due to application of liquid and soil manure (or their derivates, compost or sludge) or inorganic fertilizers. The presence of heavy metals in terrestrial ecosystems is of concern for their high toxicity and ability to be biomagnified through the food web, posing a threat to the Environmental health and survival of the resident organisms (El-Shenawy et al., 2012). This contamination causes a stress in bioindicator organisms of pollution by distorting their physiological and biochemical capacities in different degrees (Zeriri et al., 2012). Earthworms have great potential in risk assessment of contaminated land and act as an indicator for ecosystem health (Nahmani and Lavelle, 2002). The worms are capable to uptake and tolerate high levels of heavy metals, suggesting its suitability for environment monitoring (Usmani and Kumar, 2015). The Majority of studies have been conducted on toxicological effects of cadmium on earthworms Eisenia fetida. From this vision, the aim of the present study is to evaluate the toxicity of cadmium on earthworms rarely reported: Allolobophora caliginosa, by monitoring some physiological and antioxidant responses of worms exposed to a battery of high cadmium concentrations. Biomarkers can be used as early warnmg indicators of environmental contamination and potential adverse effects on populations (Peakall, 1994). In earthworms, two coexisting intracellular pathways are responsable for metal accumulation. The first involves retention of metals (particularly $\mathrm{Pb}$ ) in insoluble phosphate granules called chloragosomes (Morgan and Morris, 1982). The second pathway is the intervention of sulfur-rich ligands like metallothionein-like proteins (MTLP) able to bind metals (particularly Cd) within cadmosomes (Morgan and Morgan, 1990; Morgan et al., 1993). Since proteins "MTs" are physiologically involved in essential metal ions transport and regulation, and function as intracellular distributors of copper and zinc, they also play a role in non-essential metal regulation and detoxication (Klaassen, 1995; Klaassen et al., 1999). They are particularly known to protect cells from $\mathrm{Cd}$ toxicity and oxidative stress (Andrews, 2000). In this work, we noted in the period of 7 days a significant increase in the total proteins rate of the lowest concentration of cadmium $25 \mathrm{mg} / 500 \mathrm{~g}$ d.w, and for worms treated with the highest concentration of cadmium $150 \mathrm{mg} / 500 \mathrm{~g} \mathrm{~d} . \mathrm{w}$ this rate was very highly significantly increased. This finding is in agreement with those of Bernard et al. (2010) and Xiaohui et al. (2012), who showed an increase in the rate of total proteins of worms Eisenia fetida, Lumbricus rubellus and Lumbricus terrestris treated with increasing concentrations of cadmium. Similar induction of proteins after $\mathrm{Cd}$ exposure was already observed in aquatic organisms treated with increasing concentrations of cypermethrin which contain heavy metals (Amamra et al., 2015). However, we noted a regulation of total proteins rate in a dose dependent manner in the period of 14 days, this finding is in agreement with those of Spurgeon et al. (1994) and Matthias (2010), who showed a significant up-regulation of MT in both species Eisenia fetida and Lumbricus terrestris exposed to cadmium, The high tolerance of earthworms to cadmium poisoning is due probably to detoxification by metallothionein proteins in the posterior alimentary canal (Morgan et al., 1989). Ireland (1978) found that cadmium and lead are particularly concentrated in chloragogen cells in $L$. terrestris and Dendrobaena rubidus, where it bounds in the form of Cd-metallothioneins and $\mathrm{Pb}$-metallothioneins. The chloragogen cells in earthworms appear to accumulate heavy metals 
absorbed by the gut and immobilize the metals in small spheroidal chloragosomes and vesicles found in these cells (Sinha et al., 2008; Usmani and Kumar, 2015). All the studies including our results suggest that MT could be developed as a more effective biomarker for determining soil cadmium contamination levels. The Glutathione considered as the vital second-line defenses against oxidative damage which is the major non enzymatic radical scavenger in the animal cells (Moumeni et al., 2016) and Glutathione-s-transferase (GST) as one of phase II Enzymes can catalyze the conjugation reaction of GSH and electrophilic xenobiotics, and thus contribute to the removal of reactive electrophiles. This enzyme also plays a role in cellular protection against Oxidative stress (Xiaoxia Yang et al., 2012; Sulata et al., 2008). In the cell, there is equilibrium between the reduced and oxidized forms of glutathione which have the efficiency to provide antioxidant defenses against the heavy metal Cd on Earthworms. In our experiment, we noted a dose dependent increase in the GSH level parallel to the significant decrease of the GST activity for 7 days of exposure may be due to an up regulation of the GSH synthetic pathway and may be a protective mechanism against the toxic effects of the metal. (Sulata et al., 2008; Xiaoxia Yang et al., 2012) indicating the earthworms failed to cope with the toxic stress from exposure to $\mathrm{Cd}$ through their detoxifying and antioxidant mechanisms during a short exposure period. After 14 days of exposure, the present investigation clearly demonstrates a strong dose-response correlation between the cadmium and GSH expression. GSH expression seems to be sensitive to cadmium: it was strongly declined even at low cadmium concentration that depletion might be due to its massive utilization through the oxidation of two molecules of GSH to a molecule of GSSG. GSH also scavenges reactive oxygen species (ROS) and the Cd can be sequestered by GSH to prevent its adverse interaction with biomolecules. GSH and other thiols play a crucial role in cleaning ROS (Broerse et al., 2012; Sulata et al., 2008; Xiaoxia Yang et al., 2012). similar conclusions was reached by Saint-Denis et al. (1999), Sulata et al. (2008), and Zeriri et al. (2012), who showed a significant decrease of GSH rate on Eisenia fetida andrei exposed to benzo [a] pyryne and Octodrilus complanatus exposed to pesticide. This is in agreement with earlier studies (Moumeni et al., 2016; Amamra et al., 2015). That elucidated a significant depletion of the GSH content in paramecia exposed to insecticide, parallel to a significant increase in GST activity known that it exert the function of detoxification, Usually the depletion of the GSH leads to GST activation with a simultaneous re-synthesis of GSH for the replacement of the normal level, so it plays a major role in the metal metabolization by organisms and provide to the cell a state of equilibrium and protection against oxidized reactive species (Mofredj et al., 1999). Studies conducted on earthworms exposed to Heavy metals (such as Cd) (Brown et al., 2004, Ribera et al., 2001, Saint-Denis et al., 1999; Xiaoxia Yang et al., 2012) and to pesticide (Zeriri et al., 2012), and studies conducted on paramecia exposed to pesticide (Moumeni et al., 2016) and cypermethrin (Amamra et al., 2015) demonstrated the same results. Catalase represents an important link in the detoxification of ROS generated as a result of a toxicity, which is regarded as an enzyme presenting a clear and early response to contamination. In the present study, CAT activity was found to be increased after 7 and14 days of exposure. This increase might be due to up-regulation of CAT activity, which could be an adaptive mechanism to prevent the accumulation of toxic Reactive Oxygen Species ROS (El-Shenawy et al., 2012). This result was in agreement with the findings of Zhang et al. (2009) $48 \mathrm{~h}$ Eisenia fetida. According to Torres et al. (2002) these data suggest 
that the increase in antioxidant defenses would be due to enhanced oxygen free radicals production, which could stimulate antioxidant activities to cope with this increased oxidative stress and protect the cells from damage. LPO is a complex process in which polyunsaturated fatty acids in the biological membrane system undergo changes by chain reactions and form lipid hydroperoxides, which decompose double bonds of unsaturated fatty acids and disrupt membrane lipid (Radwan et al., 2010). After 7 and14 days of exposure, a noticeable increase in lipid peroxydation biomarker MDA was observed in Allolobophora caliginosa earthworms treated with different concentrations of cadmium. These findings are in good agreement with those of (Radwan et al., 2010) who recorded a significant elevation in MDA after $48 \mathrm{~h}$ of exposure in T. pisana snails contaminated by Cd- and Zn. Also (Zeriri et al., 2012) indicated that the level of MDA increase in earthworms treated with different concentrations of methomyl. These results were in agreement with the present data where increasing, the levels of cd elevated the LPO level in earthworms (Li et al., 2008; Xue et al., 2009) suggested that one of the most damaging effects of ROS and their products in cells is the peroxydation of membranaires lipids, who can be indicated by the detection of MDA. In conclusion, the results demonstrate that Allolobophora caliginosa earthworms are sensitive to metal toxicity. Since it showed an important oxidative stress translated by an outbreak of a system of détoxification (GSH, GST), a stimulation of the oxidative enzyme activity: the catalase. This effect is accompanied by an up-regulation of total protein and a peroxydation of the lipids (MDA). It emerges that the Allolobophora caliginosa earthworms are an excellant bioindicator model of the pollution and the state environmental. However, more research is needed for better understanding and application of results from Allolobophora caliginosa earthworms, such as how heavy metals interact with different soil types. Also more works are needed such as MT gene expression, cocoon reproduction etc, and a suite of biomarkers is helpful in the evaluation of heavy metals toxicity on earthworms and could be instrumental in monitoring soils contaminated with multiple pollutants.

\section{References}

Amamra R., Djebar M R., Moumeni O., Azzouz Z., Zeriri I., Atailia A., Benosmane S and Berrebbah H. (2015). Lipid peroxidation, oxidative stress and respiratory metabolism alteration in the freshwater ciliate Paramecium tetraurelia exposed to cypermethrin, a pyrethroid insecticide. Journal of Biodiversity and Environmental Sciences, 6, 115-123.

Andrews G. K. (2000). Regulation of metallothionein gene expression by oxidative stress and metal ions". Biochem Pharmacol. 59, 95-104.

Bengtsson G., Ek H and Rudgren S. (1992). Evolutionary response of earthworms to long term metal exposure. Oikos, 63, 289-297.

Bernard F., Brulle F., Douay F., Lemiere S., Demuynck S and Vanden-bulcke F. (2010). Metallic trace element body burdens and gene expression analysis of biomarker candidates in Eisenia fetida, using an "exposure/depuration" experimental scheme with field soils. Ecotoxicology and Environmental Safety, 73, 1034-1045.

Bradford M. (1976). A rapid and sensitive method for the quantification of microgram quantities of protein utilizing the Principe of protein-dye binding, Anal Biochem., 72, 278254. 
Broerse M., Oorsprong H. and van Gestel C. (2012). Cadmium affects toxicokinetics of pyrene in the collembolan Folsomia candida. Ecotoxicology, 21, 795-802.

Brown P.J., Long S.M., Spurgeon D., Svendsen C. and Hankard P.K. (2004). Toxicological and biochemical responses of the earthworm Lumbricus rubellus to pyrene, a non-carcinogenic polycyclic aromatic hydrocarbon. Chemosphere, 57, 1675-1681.

Capowiez Y., Rault M., Mazzia C and Belzunces L. (2003). Earthworm behaviour as a biomarker a case study using imidacloprid. Pedobiologia, 47, 542-547.

CEPA (Canadian Environmental Protection Act). (1994). Priority Substances List. Assessment report. Cadmium and its compounds." Government of Canada Environment Canada and Health Canada.

Derome J and Nieminen T. (1998). Metal and macronutrient fluxes in heavy-metal polluted Scots pine ecosystems in SW Finland. Environ. Pollut, 103, 219-228.

Draper H and Hadley M. (1990). Malondialdehyde determination as index of lipid peroxidation. Methods in Enzymology, 186, 241-431.

Edwards C.A and Bohlen P.J. (1996). Biology and Ecology of Earthworms 3rd Edition. Chapman \& Hall, London, 426.

El Shenawy N S., Mohammadden A and Al Fahmie Z H. (2012). Using the enzymatic and non-enzymatic antioxidant defense system of the land snail Eobania vermiculata as biomarkers of terrestrial heavy metal pollution. Ecotoxicology and Environmental Safety, 84, 347-354.

Habig W. H., Pabst M. J and Jakoby W. B. (1974). Glutathione S-transferases: the first enzymatic step in mercapturic acid formation. Journal of Biological chemistry, 249, 71307139.

Hopkin S.P. (1989). Ecophysiology of Metals in Terrestrial Invertebrates. Elsevier, Applied Science. London UK.

Ireland M. P. (1978). Heavy metal binding proprieties of earthworm chloragosomes. Acta. Biol. Acad. Sei. Hung., 29, 385-395.

Klaassen C. D. (1995). Casarett and Doull's toxicology: The basic science of poisons. 5th edition. New York: McGraw-Hill, 912.

Klaassen C. D., Liu J and Choudhuri S. (1999). Metallothionein: an intracellular protein to protect against cadmium toxicity. AnnuRev.Pharmacol. Toxicol., 39, 267-294.

Li Y., Zhou Q., Li F., Liu X and Luo Y. (2008). Effects of tetrabromobisphenol A as an emerging pollutant on wheat (Triticum aestivum) at biochemical levels. Chemosphere, 74, $119-124$.

Matthias B. (2010). Effets de métaux ( $\mathrm{Cd}$ et $\mathrm{Pb}$ ) et d'une substance énergétique (hmx) sur la reproduction et sur les protéines de type métallothionéine chez Eisenia andrei .Mémoire, Maitrise, Université de Québec à Montréal, 89-104.

Mofredj A., Cadranel J.F., Darchy B., Barbare J.C., Cazier A., Pras V and Biour M. (1999). Hepatotoxicity caused by Therapeutic doses of paracetamol in alcoholics. Report of 2 cases of fatal hepatitis in cirrhosis. Annales Medecine Interne., 150, 507-511.

Morgan A. J and Morris B. (1982). The accumulation and intracellular compartmentation of cadmium, lead, zinc and calcium in two earthworm species (Dendrobaena rubida and Lumbricus rubellus) living in highly contaminated soil. Histochemistry., 75, 269-285. 
Morgan J E., Norey C G., Morgan A J and Kay J. (1989). A comparison of the cadmiumbinding proteins isolated from the posterior alimentary canal of the earthworm Demlrodrilus rubidus and Lumbricus rubellus. Comp. Biochem. Physiol, 92, 15-21.

Morgan J E and Morgan A J. (1990). The distribution of cadmium, copper, lead, zinc and calcium in the tissue of the earthworm Lumbricus rubellus sampled from one uncontaminated soil and four polluted soils. Oecologia., 84, 559-566.

Morgan A J., Morgan J E., Turner M., Winters C., and Yarwood A. (1993). Metal relationship of earthworms. In: Ecotoxicology of Metals in Invertebrates. Ed Dallinger R, Rainbow PS. Lewis Publishers, Boca Raton, Fl, USA, 333-358.

Morgan J.E and Morgan A.J. (1999). The accumulation of metals (Cd, Cu, Pb, $\mathrm{Zn}$, and $\mathrm{Ca}$ ) by two ecologically contrasting earthworm species (Lumbricus rubellus and Aporrectodea caliginosa): Implications for ecotoxicological testing. Appl. Soil Ecol, 13, 9-20.

Moumeni O., Houria B., Zoubir A., Rima A., Hadjer O., Amel A., Sana B. and Reda Djebar M., (2016). Effects of Cycloxydim on Population Growth, Phagocytosis, Contractile Vacuole Activity and Antioxidant Responses in the Freshwater Ciliate (Paramecium tetraurelia). Res. J. Environ. Toxicol., 10, 115-125.

Nahmani J and Lavelle P. (2002). Effects of heavy metal pollution on soil macrofauna in grassland of Northern France. Eurasian Journal of Soil Biology, 38, 297-300.

Peakall D B. (1994). Biomarkers, the way forward in environmental assessment. Toxicol. Ecotoxicol. News, 1, 55-60.

Radwan M A., El Gendy K S. and Gad A F. (2010). Oxidative Stress Biomarkers in the digestive Gland of Theba pisana exposed to heavy metals. Arch. Environ. Contam. Toxicol, 58, 828-835.

Regoli F and Principato G. (1995). Glutathione glutathione-dependent and antioxidant enzymes in mussel, Mytilus galloprovincialis, exposed to metals under filed and laboratory conditions implications for the use ofbiochemical biomarkers. Aquatic Toxicology, 31, 143164.

Ribera D., Narbonne J F., Arnaud C and Saint Denis M. (2001). Biochemical responses of the earthworm Eisenia fetida andrei exposed to contaminated artificial soil, effects of carbaryl. Soil Biol. Biochem, 33, 1123-1130.

Saint Denis M., Narbonne J.F., Arnaud C., Thybaud E. and Ribera D. (1999). Biochemical responses of the earthworm Eisenia fetida andrei exposed to contaminated artificial soil: effects of benzo (a) pyrene. Soil Biol. Biochem, 31, 1837-1846.

Sinha R K., Bharambe G and Chaudhari U. (2008). Sewage treatment by vermifiltration with synchronous treatment of sludge by earthworms: a low cost sustainable technology over conventional systems with potential for decentralization. Environmentalist, 28(4), 409-428.

Spurgeon D J., Hopkin S P and Jones D T. (1994). Effects of cadmium, copper, lead and zinc on growth, reproduction and survival of the earthworm Eisenia fetida (Savigny): Assessing the environmental impact of point-source metal contamination in terrestrial ecosystems. Environmental Pollution., 84, 123130

Spurgeon D J and Hopkin S P. (1996). Effects of metal contaminated soils to the growth, sexual development, and early cocoon production of the earthworm Eisenia fetida, with particular reference to Zinc. Ecotox. Environ. Sare., 35, 86-95. 
Sulata M., Sonali R., Shibani C. and Bhattacharya S.. (2008). Antioxidant responses of the earthworm Lampito mauritii exposed to $\mathrm{Pb}$ and $\mathrm{Zn}$ contaminated. Soil Environmental Pollution., 151, 1-7.

Torres M A., Testa C P., Gaspari C., Masutti M B., Panitz C M N., Curi Pedrosa R., Almeida E A., Di Mascio P and Wilhelm F D. (2002). Oxidative stress in the mussel Mytella guyanensis from polluted mangroves on Santa Catarina Island. Braz. Mar. Pollut. Bull., 44, 923-932.

Usmani Z and Kumar V. (2015). Role of earthworms against metal contamination: a review. Journal of Biodiversity and Environmental Sciences., 6, 414-427.

Weckbeker G and Croy. (1988). Ribonucleotidereductase activity and growth of glutathione depleted mouse leukemia L1210 cells in vitro. Cancer letters, 40, 257-264.

Xiaohui M, Yuhui Q, Zhenjun S, Xiaofei S and Yang L. (2012). Molecular toxicity of earthworms induced by cadmium contaminated soil and biomarkers screening. Journal of Environmental Sciences, 24(8), 1504-1510.

Xiaoxia Yang., Yufang Song., Jianrong Kai and Xiufeng Cao. (2012). Enzymatic biomarkers of earthworms Eisenia fetida in response to individual and combined cadmium and pyrene. Ecotoxicology and Environmental Safety., 86, 162-167.

Xue Y., Gu X., Wang X., Sun C., Xu X., Sun J and Zhang B. (2009). The hydroxyl radical generation and oxidative stress for the earthworm Eisenia fetida exposed to tetrabromobisphenol A. Ecotoxicology., 18, 693-699.

Zhang X., Xie P., Li D., Tang R., Lei H and Zhao Y. (2009). Time-Dependent Oxidative Stress Responses of Crucian Carp (Carassius auratus) to Intraperitoneal Injection of Extracted Microcystins. Bulletin of Environmental contamination and toxicology., 82, 574578.

Zeriri I., Tadjine A., Grara N., Belhaouchet N., Berrebbah H and Djebar M R. (2012). Potential toxicity of an insecticide of the family of carbamates on a bioindicator model of the pollution the earthworm Octodrilus complanatus (Oligochaeta, Lumbricidae). Annals of Biological Research, 3 (11), 5367-5373. 